\title{
Evaluation of some respiratory functions of Kyrgyz National Team Athletes before 2016 Summer Olympic Games $^{1}$
}

\author{
Bilal Demirhan ${ }^{2}$ \\ Dciparkul Abdirahmanova ${ }^{3}$ \\ Kanat Canuzakov ${ }^{4}$ \\ Serdar Geri ${ }^{5}$
}

\begin{abstract}
In this study, some respiratory functions of athletes from four different sport branches who constitute Kyrgyzstan National Team have been examined. To research, 9 Greco-Roman style

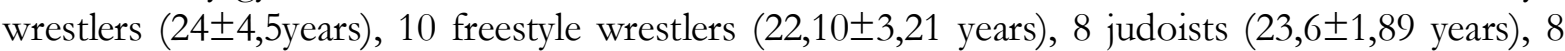
male athletes $(22,29 \pm 2.87$ years) and 3 female athletes $(21.67 \pm 2.08$ years) totally 35 male and 3 female national athletes have been included. Forced vital capacities (FVC), forced ventilation volumes (FEV1) and peak expiratory flow (PEF) which connected the respiratory levels of the athletes have been measured in preparation stage before 2016 Summer Olympic Games. By being performed istatistical evaluation by SPSS 21.0, it was used the computer package program. "One Way ANOVA" test an identifying the differences between the groups and the differences at $(\mathrm{P}<0,05)$ level have been accepted as significant. FVC values taken from Judoists were similar to those of male athletes $(p>0,05)$ and significantly higher than other branches $(p<0,05)$. FVC levels of wrestling and athletic athletes reflected similar results $(p>0,05)$. When PEF levels examined, the results of judo and male athletes have been found statistically similar ( $p>0,05)$. PEF scores of Greco-Roman wrestling, freestyle wrestling and female athletes have not been found statistically different $(p>0,05)$. FEV1 results of the judoists have been found similar to those of the GrecoRoman style wrestlers $(p>0,05)$ while these results have been found significantly higher than the results of freestyle wrestling and athletic athletes $(p<0,05)$. As a result, Judo athletes' FVC, PEF and FEV1 levels have been found better than other branches involved in the study.
\end{abstract}

Keywords: Respiratory functions; wrestling; Judo; athleticism.

\footnotetext{
${ }^{1}$ This study was presented orally at the 6th International Conference on Science Culture and Sport, 25-27 April 2018, Lviv, Ukraine

2 Assoc. Prof., Ondokuz Mayis University, Y.D. Faculty of Sport Sciences, bilaldemirhan55@gmail.com Kyrgyz Turkish Manas University, School of Physical Education and Sport, bilaldemirhan55@gmail.com 3 Assoc. Prof., Kyrgyz Turkish Manas University, School of Physical Education and Sport, jipard@mail.ru

${ }_{4}^{4}$ Prof. Dr., Kyrgyz Turkish Manas University, School of Physical Education and Sport, kanat.canuzakov@mail.ru

${ }^{5}$ Assoc. Prof ., Mardin Artuklu University, School of Physical Education and Sport, serdargeri@gmail.com
} 
Demirhan, B., Abdırahmanova, D., Canuzakov, K., \& Geri, S. (2018). Evaluation of some respiratory functions of Kyrgyz National Team Athletes before 2016 Summer Olympic Games. Journal of Human Sciences, 15(3), 17111716. doi: $10.14687 /$ ihs.v15i3.5431

\section{Introduction}

Today, the results of scientific studies on Olympic Athletes are importance in directing the training of these athletes. High-level athletes of the same branch generally have physical and physiological similarities. For this reason, it is a known fact that very small differences determined winners in competitions among elite level athletes. The development of trainings of these athletes with the help of information's gained in scientific researchers will be an important factor in achieving success.

In sports, success or performance depends on tactic and psychic factors and neuromuscular functions such as technique, speed, strength, aerobic and anaerobic energy expenditure. The performance of the individual arises because of coordinated effort, and the integration of many different functions (Açıkada \& Ergen, 1985). One of the important influence of training is on the circulatory and respiratory system (Durusoy, 1986). Respiration is the gas exchange between living organism and external environment. The most significant function of the lungs is to provide the necessary oxygen to the tissues and to transport the carbon dioxide from the tissues (Uzun, Akyüz, Taş \& Aydos, 2010).

Along with diagnosis of lung diseases and pulmonary capacities, Pulmonary Function Tests are also essential in physiology of sport. Some studies are available that assert the chronic effect of training on respiratory system (Cordain, et al., 1990; Ocak et al., 2014). In a research made by Schone et al., (1997) reported that different types of sport have different effects on lung function. Studies on the effects of exercises on respiratory parameters tend to bring different views with it. Some researchers argue that intensive physical training has an increasing effect on respiratory parameters, while others note that this development is parallel to normal growth as the dynamism of the age group (Schone et al., 1997; Ergen., 1983; Nikolic \&Ilic, 1992). Besides, some researchers suggest that exercise does not increase the respiratory parameters but makes them more efficient and economic (Kubiak-Janczaruk, 2005). Lung function tests are used to measure lung volumes and capacities and to monitor respiratory muscles, ways of breathing and expansion capacity of lung (Kayatekin at al., 1993) The main object of the pulmonary function tests is the spirometry, which introduces very important data. Forced vital capacity (FVC) and forced expiratory volume in one second (FEV1) are the two most important parameters assessed in a spirometry testing (Demir, 2017). Another parameter assessed by spirometry is the Peak Expiratory Flow (PEF) level. A spirometry is a physiological test that records the volume and flow of the air that the individual has inhale and exhale within the specified time function. As the blood pressure measurement is of utmost importance in identifying the general cardiovascular risk, so the spirometry is indispensable in determining general respiratory status (Miller et al. 2005).

From this point, this study aimed at contributing to the related studies by identifying the values of respiratory function of athletes of National team Kyrgyzstan from 4 different branches before 2016 Summer Olympic games.

\section{Material and method}

Totally, 38 athletes included in the preparations for 2016 summer Olympic games in the National Team of Kyrgyzstan from the branches of Greco-Roman Wrestling (9), Free style Wrestling (10), judo (8), male athleticism (8) and female athleticism (3) were involved in the research. The data of the research were collected under the Scientific Research Project.

\section{Height and body weight measurement}

The subjects have been weighed in up to 20 -gramm sensitive weighbridge with bare feet and shorts only.Length measurements have been taken with the Holtain slide calipers while the subjects were standing in upright position having the calipers that slide along the scale adjusted so that they can touch the heads and read with an accuracy of $1 \mathrm{~mm}$ in length. 
Demirhan, B., Abdirahmanova, D., Canuzakov, K., \& Geri, S. (2018). Evaluation of some respiratory functions of Kyrgyz National Team Athletes before 2016 Summer Olympic Games. Journal of Human Sciences, 15(3), 1711 1716. doi: $10.14687 /$ ihs.v15i3.5431

\section{Measurement of respiratory parameters}

Respiratory parameters have been measured using a COSMED spirometer. During the measurement, the subjects took the mouthpiece of the spirometer into their mouths and put on a nosepiece. The forced vital capacities (FVC), forced expiratory volume in one second (FEV1), and the peak expiratory flow (PEF) parameters were measured having subjects made a strong expiratory effort after extensive inspiration in a sitting position. This process was repeated twice and the best results were accepted.

\section{Statistical Analysis}

Statistical evaluation of the findings has been performed with SPSS 21.0 computer package program, and the arithmetic mean and standard deviation of all parameters were calculated. The "Single Sample Kolmogorov-Smirnov" test has been used to determine the homogeneity of the data. To determine the difference between the groups the "One Way ANOVA" test has been applied. Differences in $\mathrm{p}<0.05$ were considered significant.

\section{Ethical approval}

Detailed information about the study was given to the subjects before the measurements and the voluntary confirmation form get signed. The study protocol was approved by the ethics committee of Kyrgyzstan State Sports Academy no 2015/175.

\section{Results}

The demographic information of sportsmen from four different branches included in the research hare given in table 1.

Table 1: Demographic Characteristics of Kyrgyz National Athletes

\begin{tabular}{|c|c|c|c|c|}
\hline Branches & $\mathbf{n}$ & $\begin{array}{c}\text { Age (yr.) } \\
\text { (Meantsd) }\end{array}$ & $\begin{array}{l}\text { Height }(\mathrm{cm}) \\
(\text { Mean. } \pm \mathrm{sd})\end{array}$ & $\begin{array}{l}\text { Weight (kg) } \\
\text { (Mean. } \pm \text { sd) }\end{array}$ \\
\hline $\begin{array}{l}\text { Greco-Roman } \\
\text { wrestling }\end{array}$ & $9(\mathrm{M})$ & $24,00 \pm 4,50$ & $169,60 \pm 9,44$ & $72,02 \pm 11,80$ \\
\hline Freestyle wrestling & $10(\mathrm{M})$ & $22,10 \pm 3,21$ & $164,31 \pm 4,75$ & $64,75 \pm 6,34$ \\
\hline Judo & $8(\mathrm{~K})$ & $23,6 \pm 1.89$ & $175,7 \pm 36,87$ & $86,2 \pm 20,27$ \\
\hline Male athleticism & $8(\mathrm{M})$ & $22,29 \pm 2,87$ & $177,88 \pm 6,31$ & $64,98 \pm 2,72$ \\
\hline Female athleticism & $3(\mathrm{~F})$ & $21,67 \pm 2,08$ & $171,66 \pm 2,51$ & $56,5 \pm 8,58$ \\
\hline
\end{tabular}

Table 2:Measurements of respiratory volume and capacity of National athletes of Kyrgyzstan

\begin{tabular}{lccc}
\hline Branches & $\begin{array}{c}\text { FVC (Itr) } \\
\text { (Mean } \pm \text { sd) }\end{array}$ & $\begin{array}{c}\text { PEF (Itr/sec) } \\
\text { (Mean } \pm \text { sd) }\end{array}$ & $\begin{array}{c}\text { FEV }_{\mathbf{1}}(\text { Itr) } \\
\text { (Mean } \pm \text { sd) }\end{array}$ \\
\hline Greco-Roman wrestling & $3,87 \pm 0,94 \mathrm{~b}$ & $9,33 \pm 2,47 \mathrm{bc}$ & $3,27 \pm 1,26 \mathrm{ab}$ \\
\hline Freestyle wrestling & $3,7 \pm 0,77 \mathrm{~b}$ & $8,84 \pm 1,25 \mathrm{bc}$ & $2,55 \pm 1,07 \mathrm{~b}$ \\
\hline Judo & $5,27 \pm 1,22 \mathrm{a}$ & $11,18 \pm 0,59 \mathrm{a}$ & $3,82 \pm 0,74 \mathrm{a}$ \\
\hline Male athleticism & $4,49 \pm 1,95 \mathrm{ab}$ & $10,41 \pm 1,71 \mathrm{ab}$ & $2,26 \pm 1,39 \mathrm{~b}$ \\
\hline Female athleticism & $3,21 \pm 0,13 \mathrm{~b}$ & $6,96 \pm 1,34 \mathrm{c}$ & $3,07 \pm 0,07 \mathrm{~b}$ \\
\hline
\end{tabular}

abc: $\mathrm{P}<0,05$ Explain differences between column.

The forced vital capacity FVC values in respiratory functions of Judokas' were significantly higher $(p<0,05)$, than in other branches reflecting the same results in male athletes $(p>0,05)$. FVC levels of wrestling and athletic athletes reflected similar results $(\mathrm{p}>0.05)$. Peak expiratory flow PEF results of male athletes were significantly higher than female athletes $(p<0,05)$, while judokas and 
Demirhan, B., Abdirahmanova, D., Canuzakov, K., \& Geri, S. (2018). Evaluation of some respiratory functions of Kyrgyz National Team Athletes before 2016 Summer Olympic Games. Journal of Human Sciences, 15(3), 17111716. doi: $10.14687 /$ ihs.v15i3.5431

male athletes had statistically similar PEF averages( $p>0,05)$. The same can be said for wrestlers who had similar results of PEF. PEF scores of Greco-Roman and free style wrestlers and of female athletes did not differ statistically ( $p>0,05)$.The FEV1 results of Judokas were significantly higher than the freestyle wrestlers and athletics athletes $(p<0.05)$ being similar to the scores of GrecoRoman wrestlers ( $\mathrm{p}>0,05)$.

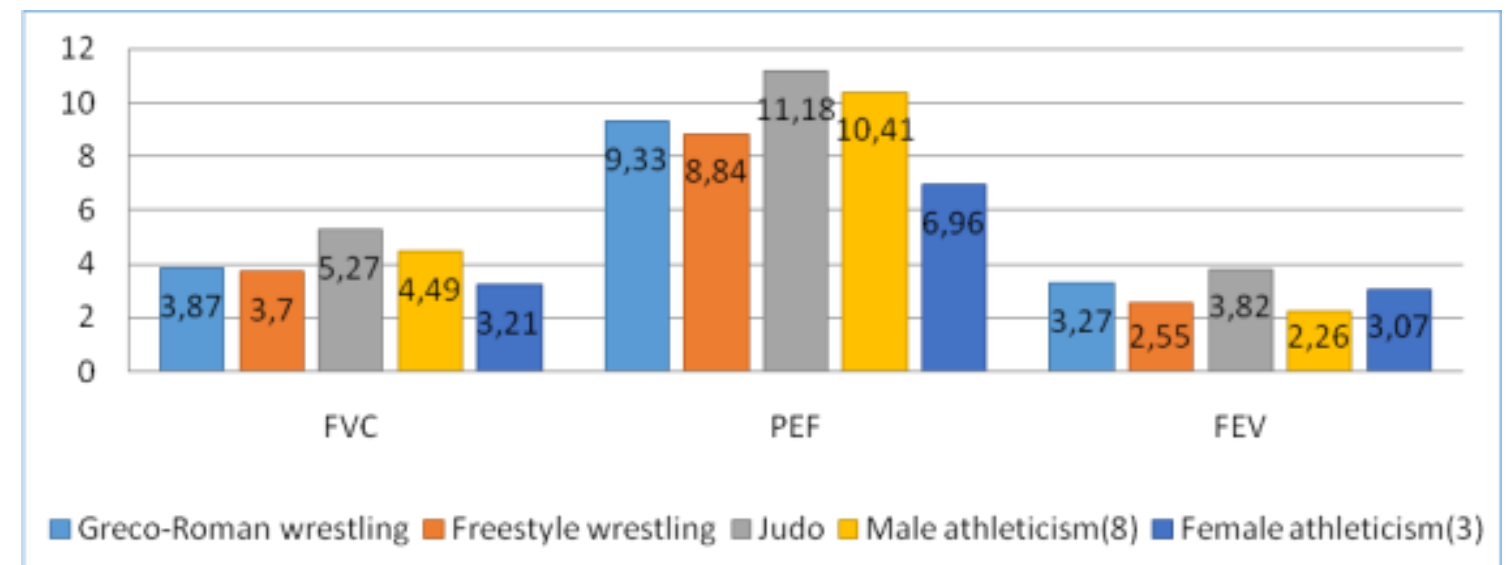

Graph 1. Graphical representation of respiratory volumes of the athletes

\section{Discussion}

In physical exercise, the muscle increases his demand for oxygen and in parallel, physiological adaptation of the respiratory system that will meet the necessary oxygen emerges. The increase in respiratory parameters due to the type of exercise; the development of respiratory muscles depend on the ability of the lungs and thorax to expand and the elasticity of the bronchi and bronchioles (Gözü, Liman \& Kan, 1998).

In this study, when the Respiratory volume and flow of the athletes of National Team of Kyrgyzstan were examined, Forced vital capacity (FVC) level of Greco-Roman wrestlers found to be 3,87 ltr/sec; while he Peak expiratory flow (PEF) score was 9,33 ltr/sec and the forced expiratory volume in one second (FEV1) was 3,27 ltr/sec. Freestyle wrestlers achieved FVC of 3.7 ltr/sec, PEF of $8.84 \mathrm{ltr} / \mathrm{sec}$ and FEV of $3.27 \mathrm{ltr}$. The FVC, PEF and FEV1 measurement results in Judokas were measured as 5,27, 11,18 and 3,82 ltr/sec. respectively. For male athletes, FVC was found to be 4,49ltr, PEF 11,18 ltr/stc and FEV1 3,82 ltr/sec. The FVC, PEF and FEV1 values of women athletes were measured as 3,21ltr, 6,96 ltr / sec and 3,07 ltr (Table 2, Graph 1). According to these results, the forced vital capacity FVC values obtained in judokas of National Team of Kyrgyzstan were significantly higher $(\mathrm{p}<0,05)$ than the other branches while reflecting similar result among male athletes $(p>0,05)$.FVC levels of wrestling and athletic athletes showed similar results $(p>0,05)$. PEF results of male athletes were significantly higher than female athletes $(p<0,05)$, while judokas and male athletes had statistically similar PEF averages $(p>0,05)$. The same can be said for wrestlers who had similar results of PEF. PEF scores of Greco-Roman and free style wrestlers and of female athletes did not differ statistically $(\mathrm{p}>0,05)$. The FEV1 results of Judokas were significantly higher than the freestyle wrestlers and athletics athletes $(p<0,05)$ being similar to the scores of Greco-Roman wrestlers ( $p>0,05)$.

According to the obtained results, respiratory functions of judo and male athletes have been found to be better than other branches. In Table 2, judo and male athletes appear to have a higher averageof body length and body weight than the other branch athletes. Our findings coincide with the studies in which height and body weight are identified as da decisive criterion of vital capacity (Moğulkoç et al., 1997; Çakmakç1 et al., 2005; Jensen et al., 1984). It can be said that, the report of 
Demirhan, B., Abdirahmanova, D., Canuzakov, K., \& Geri, S. (2018). Evaluation of some respiratory functions of Kyrgyz National Team Athletes before 2016 Summer Olympic Games. Journal of Human Sciences, 15(3), 17111716. doi: $10.14687 /$ ihs.v15i3.5431

Lazlo et al (2006) about the correlation between lung volumes and body height in their assistant guidebook is a result expected as an effect of structural state obtained in our findings.

In their research where the physical and physiological characteristics of female athletes in different branches are compared Aktur et al. (2001) noted that FVC levels of female athletes was $3.18 \pm 0.45 \mathrm{ltr} / \mathrm{sec}$, while FEV1 level was $2.96 \pm 0.29 \mathrm{ltr} / \mathrm{sec}$, and PEF level $5.88 \pm 1.10 \mathrm{ltr} / \mathrm{sec}$. In another research, Kocahan et al (2017) reported the FVC value of the judokas as 4,56 $\pm 1,101$

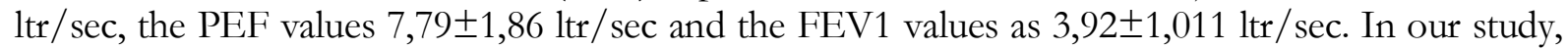
these scores have been observed to be lower than the average of the female athletes. The reason for this is thought to be the result of the fact that the average age of the athletes in the subjects of the researchers was lower than in our groups or that, the athletes in our research group consisted of elite athletes at the Olympic level and the vital capacities were more developed due to intense trainings. In another study, Albayrak et al. (2002), declared that the FVC values of professional footballers were 5,589 $\pm 0,647 \mathrm{ltr} / \mathrm{sec}, \mathrm{FEV} 1$ values 4,839 $\pm 0,595 \mathrm{ltr} / \mathrm{sec}$, and PEF levels were $9,817 \pm 1,567 \mathrm{ltr} / \mathrm{sec}$. These scores obtained from professional footballers are important in what they are similar to the results we received from Olympic athletes. Özen et al. (2011) reported that elite climbers have FVC averages of 5 (4.1-5.3) ltr/sec, FEV1 averages of 4 (3.8-4.8) ltr/sec and PEF averages of 572 (486-658) ltr/sec. In his research conducted on the respiratory functions of canoe athletes Dokumaci et al. (2015) observed that their FVC levels were $5.88 \pm 0.75 \mathrm{ltr} / \mathrm{sec}$. while FEV and PEF levels were $4.077 \pm 0.92 \mathrm{ltr} / \mathrm{sec}$. and $5.948 \pm 2.30 \mathrm{ltr} / \mathrm{sec}$.

\section{Conclusion}

In our study, the forced vital capacity (FVC), forced expiratory volume in one second (FEV1) and peak expiratory flow (PEF) levels of wrestlers, judokas and athletic athletes of Kyrgyz national team coincide with the literature. According to the results obtained in the research, it has been concluded that, the reason why Judo athletes have better respiratory functions than other branch athletes may be explained with the difference in height and body weight.

\section{Acknowledgement}

This article has been produced from Kyrgyzstan-Turkey Manas University KTMÜ-BAP: 2015.FBE.06 scientific research project. The project was supported by the Department of Olympic Sports under the Ministry of Sport of Kyrgyzstan and Bishkek Coordinator of Turkish Cooperation and Coordination Agency (TIKA).

\section{References}

Açıkada, C., Ergen, E. (1985).Dayanıklilı̆̆ın Geliştirilmesi, BilimTeknik Dergisi, 2, 34.

Akdur, H., Taşkıran, H., Çıtakoğlu, S., Yiğit, Z., \&Özerka, K., (2001). Farklı Branşlardaki Bayan Sporcuların Fiziksel ve Fizyolojik Özelliklerinin Karşılaştırılması. Gaz̧i Beden Eğitimi ve Spor Bilimleri Dergisi, 4( 2),3-11.

Albayrak, S.Y., Kayserilioğlu, A., Dinçer, C., Kaşıç̧ığlu, E.,\& Ünal, M. (2002). Profesyonel ve Amatör Futbolcuların Hematolojik ve Solunum Parametrelerinin Karşılaştırılması. İst Tpp Fak. Mecmuasi, 65(1), 30-33.

Çakmakçı, O., Fişekçioğlu, İ.B., Çınar, V., Akkuş, H., \& Kılıç, M. (2005). Türkiye ve Gürcistan A- Milli Boks Takımlarının Bazı Solunum Parametrelerinin Karşılaştırılması. Beden Eğitimi ve Spor Bilimleri Dergisi, , 3(4) 133-136

Cordain L., Tucker, A., Moon D.,\&Stager JM. (1990). Lung Volumes and Maximal Respiratory Pressures in Collegiate Swimmers and Runners. Res Q Exerc Sport, 61(1), 70-74

Demir T. (2017). sprometry and flow-volume curve. Toraks Cerrabisi Bülteni; 10: 9-15 
Demirhan, B., Abdirahmanova, D., Canuzakov, K., \& Geri, S. (2018). Evaluation of some respiratory functions of Kyrgyz National Team Athletes before 2016 Summer Olympic Games. Journal of Human Sciences, 15(3), 17111716. doi: $10.14687 /$ ihs.v15i3.5431

Dokumacı, B., \& Atabek H.Ç. (2015). Relationship between anthropometric variables, respiratory function and bio-motoric properties in Turkish flat water canoe athletes, International Journal of Social Sciences and Education Research, 1(3),758-765.

Durusoy, F. (1987). Dolaşım, Solunum Sistemi ve Spor. Spor Hekimliği Dergisi, 22(4), 15-18

Ergen, E. (1983). Egzersiz yapan çocuklarda akciğer volüm değişiklikleri. Spor Hekimlï̆i Dergisi, 18(3), 131-141.

Gözü, R.D., Liman, E.» \& Kan, I. (1988). Thoraks ölçümleri ve Solunum Fonksiyonlarının antrenmanlarla Değişimi. Spor Hek. Derg, 23 (1), 1-8.

Jensen, K., Sccher, N.H., Fiskestrand, A., Christensen, N.J.,\& Lound, J.O. (1984). Influence of body weight on physiologic variables measured, during aximal dynaic exercaise. Acta Physiologica Scandinavica, 121,39A

Kayatekin, M., Şemin, İ., Selamoğlu, S., Çeçen, A., Avar, L., \& Acarbay, Ş. (1993). Turgay F. Profesyonel ikinci lig futbol takımlarında oynayan otuzüç futbolcunun sezon öncesi fizyolojik profilleri. Spor Hekimliği Dergisi, 28, 117-23.

Kocahan. T., Akınoğlu. B., Çoban. Ö., \& Yıldırım. N.Ü. (2017). Yapılan Sporun Karakteristiği Solunum Fonksiyonlarını Etkiler mi? Voleybol ve Judo Sporcularının Karşılaştırılması: Pilot Çalısma. Online Türk Sağhlk Bilimleri Dergisi, 2 (2), 27-33.

Kubiak-Janczaruk E. (2005). Spirometric evaluation of the respiratory system in adolescent swimmers. Ann Acad Med Stetin, 51(2), 105-113.

Laszlo G. (2006). Standardisation of lung function testing: helpful guidance from the ATS/ERS Task Force. Thorax.61(9),744-746.

Miller M.R., Hankinson J., Brusasco V., et al. (2005). Standardisation of spirometry. The European respiratory journal, 26(2), 319-338.

Moğulkoç, R., Baltacı, A.K., Keleştimur, H., Koç, S., \& Özmerdivenli, R. (1997).16 Yaş Grubu Genç Kızlarda Max VO2 ve Bazı Solunum Parametreleri Üzerine Bir Araştırma. Gaz̨i Üniversitesi Beden Egitimi ve Spor Bilimleri Dergisi, 2(1), 11-18.

Nikolic, Z., \& Ilic, N. (1992). Maximal oxygen uplake in trained and untrained 15 year old boys. Br J of Sports Med, 26(1), 36-38.

Ocak, Y., Savas, S., Isik, O., \& Ersoz, Y. (2014). The effect of eight-week workout specific to basketball on some physical and physiological parameters. Procedia-Social and Behavioral Sciences, 152, 1288-1292.

Özen, S.., Sönmez G.T, \&Özen G. (2011). Anthropometric, Strength and Pulmonary Characteristics of Elite and Non Elite Sport Climbers. e-Journal of New World Sciences Academy, 6(2), 104-113.

Schoene, RB., Giboney, K., Schimmel, C., Hagen, J., Robinson, J., Schoene, RB., Sato, W., \&Sullivan, KN. (1990). Spirometry and a airway reactivity in elite track and field athletes. Clin J of Sport Med, 7:257-261.

Uzun, A., Akyüz, M., Taş, M., \& Aydos, L. (2010). Analyzing Relationship between Respiratory Functions and Some Anthropometric Parameters in Young Elite Wrestlers. Nigde University Journal of Physical Education and Sport Sciences, 4 (1), 10-17. 